\title{
Creating Options: Forming a Marshallese \\ Community in Orange County, California
}

\author{
Jim Hess, Karen L Nero, and Michael L Burton
}

\section{$\mathrm{W}_{\mathrm{e}}$}

describe the development of a Marshallese community in Orange County, California, from the late I970s until the early I990s. It is among the older and larger Marshallese communities in the United States; other substantial Marshallese communities are centered in San Diego, California; Eugene, Oregon; Springdale, Arkansas; and Enid, Oklahoma (Allen I997). Smaller communities exist in Texas, Missouri, Arizona, and elsewhere in California. These communities originated in the travels of students for higher education while the Marshalls were under US administration. Since 1986, a Compact of Free Association between the new Republic of the Marshall Islands and the United States has allowed Marshallese people to migrate freely to the United States, leading to the creation of new Marshallese communities there, as well as the expansion of existing communities. We estimate that three-to-four thousand Marshallese now live on the US mainland, plus over two thousand in Hawai' $i$.

We began research in the Orange County Marshallese community in I988. In addition to participant observation and ethnographic interviews, we obtained data from a survey of individual migration, education, and employment histories; and from household censuses conducted in I99I92 and 1995 .

Just southeast of Los Angeles, Orange County is mainly urban and densely populated, with large Latino, Vietnamese, Chinese, Korean, and Iranian communities. In I99I the Orange County Marshallese community had nearly three hundred people distributed among forty-three households. Most of the Marshallese live in ethnically mixed blue-collar neighborhoods whose per capita incomes are close to the California mean. Initially more dispersed among the cities of Orange County, Marshallese households have become centered in Costa Mesa, a city of I००,০০০, where 
they are concentrated in two neighborhoods, nicknamed Downtown and Our Town. Our 1995 census indicated that the population had increased about 8 percent per year to around four hundred, and it continues to grow today.

The Orange County Marshallese community has become in many ways an "official" migrant community, with a high degree of formal recognition by the Marshallese government. The community has hosted public meetings convened by the president and his cabinet when they came to the United States, and for several years the Marshallese government had a consulate in Orange County. The history of this community illustrates the effects of political interests, the key role of education, mediation by diverse institutions, and the importance of connections through both family and nonfamily networks in facilitating the international movement of people.

\section{Migration Theories and Pacific Island Migrants}

Migration theories based on micro-economic models of individual decisions or macro-structural effects of the "world system" (Wood I982; Massey and others I993) have been concerned largely with labor migration. Taken together, they leave a gap between the micro level of individual action and the macro level of societal-level forces. In attempting to fill this gap, researchers have given particular emphasis to households, as units that make migration decisions (Wood I982) and play a key role in migrant adaptation (Chavez I985). These approaches still underrepresent macro-structural processes other than the economy, motivations other than employment, and social institutions other than households (Salt I989).

Researchers studying Pacific Island migration have provided more ethnographically based insights into the motivations and experiences of migrants. Scholars have emphasized cultural identity within migrant communities (Lieber 1977b; Linnekin and Poyer 1990), the effects of migration on gender and family (Gailey 1992; Marcus 1993; Small 1997), the role of social networks and religion in facilitating migration (Ravuvu I992), and the long-term persistence of social ties between migrant communities and home communities (Macpherson I994). Much of the discussion of these social ties has focused on remittances.

Dennis Ahlburg and Michael Levin argued for a "human capital" model of Pacific Island migration, in which people travel to gain higher returns on investments in human capital such as education, with additional destination attractions such as climate, entertainment, and consumer goods 
(1990). Bernard Poirine emphasized the role of migration in human capital formation. He viewed remittances as part of an "informal family credit market" involved with human capital investments, where remittances are a return by children of the parents' investment in their education $(1998,75)$.

The MIRAB model linked Pacific Islander migration to a pattern of economic dependency upon migration, remittances, aid, and bureaucracy, conceptualizing families as firms that allocate persons and resources (Bertram and Watters 1985). Although this was an advance in terms of an economic explanation, it is still under-attentive to social and cultural process and perpetuates a flawed model of Pacific nation-states dependent on metropolitan countries. Ker ry James emphasized the broader social context of exchanges between migrants and the home community, seeing cash remittances as part of a larger network of exchange relationships, organized at the family or community level (I997). For James the MIRAB emphasis on remittances produced an under-recognition of counterflows of other exchange items, such as Tongan wealth items, which are produced by women's labor. In a similar vein, Matori Yamamoto discussed the role of fine mats in ceremonial exchanges in several Samoan diaspora communities ( I997).

Anthropologists have long recognized that people invest in social relationships that may yield social, political, economic, or psychological returns. Sociologists have recast these processes in economic metaphors that have proven useful for introducing social relationships into otherwise narrowly neoclassical economic models. Writing about Cuban migrants, Alejandro Portes and Julia Sensenbrenner (I993) used Pierre Bourdieu's (1985) concept of social capital to refer to the social resources within a migrant community. James Coleman distinguished between human capital and social capital: "human capital is created by changes in persons that bring about skills and capabilities that make them able to act in new ways. ... Social capital, however, comes about through changes in the relations among persons that facilitate action" ( 1988 , I00). Coleman listed several social relations that form social capital, including exchange obligations, information channels, family relations, and community organizations. Social capital explains the advantages of spatial clustering of migrants, but this form of capital does not depend strictly on place. For Marshallese in Orange County, social capital is obtained partly through the maintenance of ties with the home islands.

Recently, Ramon Grosfoguel and Hector Cordero-Guzman have argued that social capital models fail to recognize government policies that affect the "context of reception" of migrant groups (I998). They claim that 
Cuban migrant success is better explained by US government support for Cuban migrants-a political process-than by social capital.

Along with many cultural anthropologists, Grosfoguel and CorderoGuzman favor the transnational approach to migration, which discards the older emphasis on migrant adaptation and focuses instead on migrants' social, economic, and cultural relationships across multiple locations (Basch, Glick Schiller, and Blanc r994; Gupta and Ferguson 1997). The transnational approach emphasizes a more complex view of a world in which identities in multiple communities remain important, and social, economic, and political relations are "unbound" by state borders. As globalization theorists emphasize, forces driving the increase in transnationalism include enhanced transportation and pervasive and inexpensive electronic communications and media (Hannerz 1992).

We see these various theories as cumulative. Transnational associations of Marshallese support migration for jobs, but also for education, amenities, health care, and various other purposes. Social and human capital are important factors in this process, which is embedded in US geopolitics as mediated by multiple Marshallese and American institutions. Circulation of individuals and families is possible, and economies as well as social systems may be spread across locales. We further argue that the general framework for transnational exchanges does not entail any particular configuration of exchanges. Particular exchange relationships are shaped by specific historical circumstances, and by a variety of political relationships between island nations and metropolitan Pacific rim nations. If that relationship takes a unique turn, as has happened with the compacts of free association between the United States and the new Micronesian states, then the exchange relationship itself may take a new form. We describe a situation in which the overseas community was created through the pursuit of education and not labor migration, where relatively high incomes are available from rents paid for strategic assets and military facility land use as well as compensation for nuclear testing, and where remittances (gifts and money) are more often sent from the island community to the migrant community than in the reverse direction.

\section{Marshallese Mobility}

The history and social institutions of the people of Aelon Kein (These Islands) have shaped Marshallese migration practices. The Ralik (western) and Ratak (eastern) chains of atolls and the western outliers of Enewetak and Ujelang, which today constitute the Republic of the Marshall Islands, 
were settled by seafaring peoples between two and three thousand years ago. Contrary to common conceptions of "insularity," island peoples in general, and especially those dwelling on fragile atolls, are highly mobile and maintain active interisland linkages (Alkire I989; Nero 1997). For example, in the Marshall Islands, the population of Ebon in the 1850 s was "always in flux" (Hezel 1983, 203); between twenty and thirty percent of all residents would depart or arrive with the iroij (chiefs) as they traveled with their courts to receive tribute and conduct business.

Marshallese social structure facilitates a high level of spatial mobility, with individuals and families traversing networks of geographically dispersed households linked by kin. The bases of Marshallese social structure are land rights and bwij (usually glossed as matrilineages, but see Carucci 1997). Kinship is bilateral, but bwij membership is primarily traced through female descent, and bwij are joined in exogamous matriclans.

Bwij have use rights in one or more parcels of land, called weto. This strip of land, generally a few hundred feet wide, crosses an island from lagoon to ocean so as to include the various ecological zones and thereby provide the bwij with access to the various plant species necessary to maintain life. The weto is central to Marshallese identity. As one informant said, being a Marshallese is having land from the first moment you draw breath. A bwij's several weto are often dispersed across a number of islands in an atoll, any of which may be used for residences, and people shift between weto. Bwij are not named, but weto are, and the weto can be used to designate relationships. The island, atoll, and island chains in which weto are located become hierarchical levels of identity as a Marshallese person moves farther out into the world.

A woman's children have equal rights to use the resources of a bwij's land, under the management of the senior member of the bwij or alab. These rights are shared with other bwij members and affines (Carucci 1997; Kiste 1974; McArthur 1995; Rynkiewich 1972; Spoehr 1949; Tobin I954). Land use rights extend through paternal links to the weto of father and grandfather. A Marshallese married couple thus usually has access to the households of parents, siblings, and parents' siblings, through both husband's and wife's sides. Households are large and complex by comparative standards (Burton, Nero, and Hess 2000). Individuals or groups frequently move among these households for personal, social, or economic reasons. With increased inter-atoll marriages, available households also may extend through more than one atoll; hence internal migration does not usually require the establishment of a new household. Land rights through clans on other islands or atolls constitute another mechanism for 
population mobility. Historically these rights were often exercised when drought or typhoon damaged a group's lands and crops. Finally, expansionist high chiefs, iroij laplap, initiated wars to extend their holdings. Grants of land rights by the chief for services rendered established another mechanism for diversifying land rights and population mobility.

\section{Colonial Contexts}

Colonial enterprises refocused population movements to favor labor migration and resource extraction and introduced wholesale community relocations. On Likiep, many people were relocated after two European copra traders purchased it for use as a plantation. Marshallese also were involved in the Pacific labor migrations of the late 1860 s and I870s, working in the phosphate mines of Nauru (Underwood 1989) or as plantation labor in Fiji, S moa, or Hawai' $i$, while women of the northern atolls were taken for sale as mistresses to plantation overseers (Westbrook 1935, I97; Hezel I983, 237-240). The German (I885-I9I4) and Japanese (I9I4-I945) administrations emphasized copra production and trade and built up Jaluit as an administrative center that attracted people seeking jobs, education, and other services. At its height Jaluit was home two thousand Marshallese, approximately 20 percent of the native population, as well as between five hundred and a thousand Japanese (Peattie I988, I86). Construction of Japanese military installations forcibly displaced major portions of the Marshallese communities on Enewetak, Kwajalein, Majuro, Mili, Maloelap, and Wotje, and entire populations were relocated during the Second World War.

Population dynamics underwent further changes during the US administration. Again entire communities were relocated, to enable the US nuclear tests on Bikini and Enewetak (Kiste 1974; Mason 1954; Tobin 1967) and the development of a missile test base on Kwajalein (Mason 1989). During the US period the Marshallese population grew rapidly (Gorenflo and Levin 1995), and two dense urban concentrations developed. The first is on Ebeye islet in Kwajalein Atoll, where relatively high wages have brought Marshallese, their dependents, and people from throughout the Pacific (Alexander 1978). The second urban center is in the Djarrit-UligaDelap district of Majuro Atoll, administrative center under the US trusteeship and national capital since independence. Most population growth has been in these two urban centers. Most of the other Marshallese atolls have also experienced population growth, but their age structures are 
skewed by the movement of the burgeoning school- and working-age population to the new urban centers (Gorenflo and Levin I995). Currently about 67 percent of all residents live on Majuro or Kwajalein atolls, with the remainder scattered over the other twenty-two inhabited atolls and islands. Twenty-four percent of all Marshallese resided on a different atoll in 1988 than in 1980 .

By the I 980 os the Marshallese nation had become mainly urban, and many Marshallese had participated in wage employment. Projections based on the I 988 national census population of 43,380 predicted future populations as high as 215,000 by 2035 (RMI I989). A new census in I999, however, showed only 5I,000 resident Marshallese, 4,000 to 9,000 below the projections. Although part of the difference is due to a moderate decline in the birth rate and an overestimation of growth rates due to enumeration errors in earlier censuses, the largest part of the difference has been attributed to migration (MIJ, I999). Highly mobile Marshallese have incorporated new regions into their social geography.

\section{Education AND Migration}

The seeds of the Orange County Marshallese community were planted in the late I940s when the US government decided to maintain military control over Micronesia (Kiste I993). Initially, Micronesians' rights to reside in the United States were restricted primarily to students, members of the military, and spouses of American citizens. Marshallese migrants included some young women who married Americans; these "aunties" later served as a social resource for new arrivals. Some dozens of Marshallese also traveled to the United States as students, but there appear to be no data on whether any remained and settled.

In response to international criticism of the US role in Micronesia, the I962 Solomon report recommended expansion of education and social services in the Trust Territory (Kiste 1993). The United States greatly increased spending on social services, expanding educational opportunities, building new schools, and hiring many Peace Corps teachers. Scholarships were created for tertiary education, and in 1972 Micronesians became eligible for US federal education grants. Education was seen by Micronesians as a way to gain access to the new jobs that were created in the islands' public sector (Hezel and Levin 1987). At the same time, demographic changes in the United States put many colleges in a financial bind, and some of them sought to fill empty places by recruiting Micro- 
nesian students. High school guidance counselors in Majuro and Ebeye recommended community colleges in the United States on the basis of personal knowledge or catalogs supplied by the institutions. In the midI970s, leaders in the Marshalls called for students to pursue higher education to help the future development of their communities. More Marshal-

Table I. Micronesians Enrolled in College, by State of Origin, I962-1985

\begin{tabular}{lccr}
\hline Year & $\begin{array}{c}\text { Marshall } \\
\text { Islands }\end{array}$ & $\begin{array}{c}\text { Federated States } \\
\text { of Micronesia }\end{array}$ & Palau \\
\hline 1962 & 15 & 32 & 49 \\
1966 & 34 & 95 & 85 \\
1970 & 56 & 240 & 193 \\
1974 & 157 & 596 & 309 \\
1979 & 357 & 1,174 & 528 \\
1985 & 178 & 1,380 & 441 \\
1973 population* & 24,333 & 64,480 & 13,127 \\
\hline
\end{tabular}

Sources: Adapted from Hezel and Levin 1987; population figures from the 1973 Trust Territory census.

Notes: Does not include students enrolled in extension programs. These countries did not exist throughout the period; numbers for the FSM are aggregated from the TTPI districts, now states of the FSM.

* De jure population by home area.

Table 2. Marshallese in Orange County by Age Group and Period of Arrival

\begin{tabular}{lrrrrcccr}
\hline \multirow{2}{*}{$\begin{array}{l}\text { Period of } \\
\text { arrival }\end{array}$} & \multicolumn{7}{c}{ Age group on arrival in United States } & \\
\cline { 2 - 6 } & $0-8$ & $9-17$ & $18-26$ & $27-35$ & $36-44$ & $45-53$ & $54+$ & Total \\
\hline $1970-1974$ & 1 & 1 & 5 & 1 & 0 & 0 & 0 & 8 \\
$1975-1979$ & 5 & 9 & 31 & 3 & 0 & 0 & 0 & 48 \\
$1980-1984$ & 8 & 13 & 6 & 3 & 1 & 0 & 2 & 33 \\
$1985-1989$ & 12 & 37 & 22 & 6 & 2 & 2 & 3 & 84 \\
Total & 26 & 60 & 64 & 13 & 3 & 2 & 5 & 173 \\
\hline
\end{tabular}

Source: Hess, Nero, and Burton I99I. 
lese graduated from high school, and increasing numbers enrolled in colleges (table I).

Before 1980 most migrants to Orange County were in the college-age group ( $18-26$, table 2), and the early migrants who enrolled in Orange County schools formed the nucleus of the new community. Among these schools, Southern California College ${ }^{1}$ has played a special role. It is affiliated with the Assemblies of God, an important denomination in the Marshall Islands. Its early students have often provided leadership as officers and founders of the community club, and community members used to hold church services on campus.

\section{COMMUnity Formation}

Which factors led to the formation of Marshallese overseas communities? Many observers noted that in the I980s the Marshallese traveled less frequently in pursuit of education, advancement, and adventure, compared to other Micronesian peoples (Nero and Rehuher 1993). Nevertheless, students came, and some, like Emiko, ${ }^{2}$ who was attending school full-time after she moved from Kansas to Costa Mesa in 1978, made a transition: "When I came here my parents didn't know I was in California. They got mad with me coming here because they heard the reputation of the kids here, so they stopped sending me money, so I had to find some kind of job in order to help out with my cousin." When interviewed, she was married, had children, was working full-time, and was thinking about taking wordprocessing courses. She had not achieved her original goal, which was to get a college degree and return to a good job in the Marshall Islands.

Some students stayed in the United States after leaving school. Often this was occasioned by the birth of a baby, which helps to transform a young Marshallese from short-term student to long-term resident and may lead to the establishment of a local household. The newborns' requirements for care and financial support led many young parents to drop out of school and take jobs. A job decreases dependence on ties to home and increases ties to the local community. It increases a person's ability to acquire consumer goods that are either not available or relatively expensive in the islands.

Births are also an important factor in the growth of the Orange County community. Children born in the United States accounted for 30 percent of the community membership in I99I. The birth rate has increased significantly in recent years, so that the fertility rate in the community at the time of our study was comparable to that in the Marshall Islands. One 
mother said the community would now "bloom with kids." The existence of these children, who hold US citizenship, has implications for the future growth and permanence of the community.

Marriages are almost entirely with other Marshallese, a process aided by a balanced sex ratio. In the Orange County community, 79 males and 78 females over the age of fifteen arrived in the United States between I970 and 1989. This figure suggests a high degree of gender balance in migration to the United States, but it may be affected by a selection bias; people who do not marry form fewer ties that would keep them in the United States and hence would be more likely to return home. Recently, however, several young women have married non-Micronesians, thus increasing extra-community ties, the likelihood of permanent US residence, and community diversity.

Once a family has formed, life is expensive in California, mainly because rents are high. As a result, it can be difficult to accumulate enough money for trips to the islands. As the community grows, community activities make increasing demands on members' time and financial resources. One interviewee said travel costs kept some people in California, and thought the Orange County community made big demands on people and did not like to see anybody get too far ahead as their success would shame the rest. Community support is a cost of building social capital. The attendant expectations of providing support to others in the community may deplete family resources and reinforce the ties and constraints that bind people to the community.

Few of the Orange County Marshallese settled originally in Orange County. Most were dispersed throughout the United States. Robert Franco noted the dispersed nature of Micronesian immigrant residence in the United States compared to the dense networks of Samoan communities and questioned whether Micronesian networks could provide the community support to facilitate future immigration as Samoan communities do (I993). For the Marshallese, at least, the answer is affirmative, as the Orange Countyand other communities have coalesced through resettlement within the United States and then expanded by hosting new migrants.

Why did the community form in Orange County, given that many people first lived elsewhere in the United States? We suggest that several factors were at work. The first is proximity to the Los Angeles International Airport, a major point of entry for flights from and to the Pacific. Orange County is a convenient stopover for people on their way to other parts of the country, making the community a popular location for meetings with 
Marshallese people who are en route to other destinations. Further, it is relatively economical for Marshallese to visit home. The second factor is the mild climate. A third factor may well have been the favorable California economy of the r970s and r980s. The defense build-up of that time created new jobs in California during the late I970s and the I980s, in both defense plants and related service industries. Orange County, in particular, has had consistently low rates of unemployment.

Finally, there is the lure of Disneyland. Emiko, originally a student at a Kansas school, reported, “We didn't go home for the summer. We decided to come here to go to Disneyland. . . . and then we ended up staying." A female elder stated, "First I came here to visit my daughter and secondly I wanted to see what I always saw in the movies and what other people were talking about, how the US was the greatest in the whole wide world. I cannot name all the good things about the US but the things that captured my attention were I had never seen a lot of food and mountains, hills, big trees. Then I went to all these places except for Disneyland. Maybe this time I'll try to go to Disneyland."

\section{Migration Processes}

Older Marshallese who live in Costa Mesa, California, reported a variety of migration histories. Ester's interview illustrates the diverse processes of Marshallese migration over several generations.

My parents were born and raised on Namdrik. And they travelled with the iroij on Namdrik but mainly they went to Ailinglaplap. Now during these American times they went to Majuro for medical treatment. But they spent most of their lives in Namdrik. I was born and raised on Namdrik with my parents until 1938. My parents sent me to stay with my auntie on Ebon to attend school. And after I went to Jaluit to continue my education, just like high school during the Japanese time. [After the war Ester returned to Namdrik, married, and had children. She and her husband moved to Majuro, where he got a job.] Another reason we decided to stay in Majuro, because my older children started to go to school and it was better for my children, because the school in Namdrik has low standards. In 1980 the government started an old age program that ... taught younger generation about Marshallese culture, custom, and also handicrafts. After ... training in Majuro, the government sent them back to Namdrik to teach the children there. In I983, I came to US from Namdrik. . . . my daughter got married to a peace corps on Namdrik. After that they went to Hawai' $i$ and then decided to come to United States. In I983, they wanted me to visit them here [Costa Mesa] for the first time, and 
I stayed for six months and I went back. But that time was the time that it was hard for the Marshallese to come to US, but the reason I wasn't having any trouble is because my son-in-law was a citizen here and I came as a visitor.

In I990 I came back because my daughter needed me to take care of her daughter. . . . I didn't plan to come back because I didn't have any money. But this time my daughter paid my way here. . . . I really want to go back but my daughter has to pay my ticket and she wanted me to wait ... for the church group this summer so that it will be cost less if we went as a group.

This interview illustrates the diverse factors that have affected Marshallese migration. In her case, these include travel with the iroij, health care, wage employment, Marshallese and US government programs, church membership, marriages, family ties, and family obligations. These processes occur within a network of linked households, where migrants can find temporary shelter or a longer-term residence. These various factors have been involved in changes over time in the composition of the Marshallese migrant community in Orange County.

\section{Migration Patterns in the Early i980s}

From 1979 until the mid-I980s the number of Marshallese arriving in Orange County decreased. During this period fewer high school graduates arrived, and in education the emphasis shifted to younger Marshallese relatives of Orange County residents, primarily of high school and junior high school age (table 2). A shift among youth toward children under age eighteen was motivated in part by problems encountered by earlier arrivals in coping with the US educational system (Shmull I978). Few of the Marshallese schools prepared students to perform at the level expected of firstyear college students, and limited language skills were often a hindrance. Perhaps just as important were cultural differences in time management and the relatively high importance of social obligations versus school activities; these affected class attendance and completion of requirements "on time." Many families began to send youth to the United States earlier to help them to prepare better for college. It was increasingly possible to send these younger students because they could live with family members.

Over time, foster parenting of young people for their education has become a major aspect of community life. By the time of our I99I census, I6 percent of all community members were persons under the age of twenty-two who were living in households with relatives other than their 
parents. Sixty-three percent of all households had at least one such member. Other young students were taken in by Americans who had worked in the Marshalls and forged ties with their families.

Also during the I980 there was a decrease in overall Marshallese college enrollments (table I) following the implementation of Marshallese self-government in 1979. Informants reported that jobs in the Marshalls were then opening up as the new ministries were staffed. Many of these new opportunities required only a high school education. With good jobs opening in the Marshalls, many saw little reason to take on the risks and expenses of overseas travel. Also, some of those interviewed noted new problems in the handling of scholarships, such as failure to pay awards on time, which discouraged some applicants and forced some students to drop out.

\section{Patterns in the Late i980s}

In the mid and late I980s, migration demographics changed again. The number of arrivals increased from I984 to I988, followed by a decline during the 1989-I99I recession. Adolescent students continued to predominate among migrants, but the number of people in all age categories increased. The most significant factor in this increase was the implementation of the Compact of Free Association in late 1986, which gave all Marshallese citizens access to the United States and secured the residential rights of many who were no longer students.

The advent of free entry in the postcompact period brought the first signs of labor migration, and arrivals of people between the ages of eighteen and forty-four increased. Migration also rose for other family purposes. An example is the case of a couple in their thirties who had been students in the United States and returned to the Marshalls to work in government jobs. They decided to move back to the United States with their younger children, so that the children could get a better education. After six years they became sufficiently established to bring over their older children and several nieces for enrollment in high school.

\section{ELDERS}

The postcompact period also saw the arrival of many senior adults. An elderly woman described her experience. Her story has elements common to those of many elders living in the community. 
My oldest daughter went to high school in Palau for one year and went to Majuro for another year and finished her high school year in Costa Mesa High. Most of my children came here and graduated from Costa Mesa High. But my other son, he came here and went to Orange Coast College for two and half years but he didn't complete it. There wasn't any problem in expenses because we always sent money to the sponsor here to help.

In 1984 , I came to stay with my children and take care of them while they went to school. We planned that I came here just to visit my children, but while I was here I changed my mind to stay. My husband stayed for only few days and he went back, because he wanted to try to run for senator and he wanted to prepare whatever he had to do.

The move to the United States is but one of a series of life transitions for many elders. Taniel attended Japanese school in Jaluit, then worked for the Japanese until he was clandestinely evacuated from Jaluit by the US military during the Second World War. After the war Taniel moved to Namdrik to make copra. In I970 he moved to Majuro to work for a brotherin-law. He then found government employment as a janitor, and in I99I he was living on his retirement income in Orange County.

Reasons given by informants for the migration of elders included the desire of elders to be with children and grandchildren, interest in seeing the United States, helping working parents with household work, and the role of elders in managing family affairs, conflict resolution, and health care. Older people sometimes come to obtain treatment not available in the Marshall Islands, and some stay long enough to seek eligibility for medical aid or supplemental security income. However, in one case, the direction of medical services was reversed: an older woman skilled in traditional Marshallese therapeutic massage techniques came to California to help her daughter with a difficult pregnancy. She stayed and helped relatives with other medical problems such as a broken leg, removing the hospital-imposed cast to apply massage therapy.

Community members move people between locations as a strategy for dealing with social conflict. We heard four reports in two years of individuals sent by their families to Orange County, generally for a period of a few months, to remove them from conflicts at home. Conversely, one young man reported that after he graduated from high school, he was just hanging around and getting into trouble, so his uncle sent him back to the Marshalls. Married and with family responsibilities, he recently returned to Orange County with his family to find work. 
These practices are the direct consequence of the removal of barriers to Marshallese migration. Now Marshallese can follow island practices of moving family members across locations as necessary, for many reasons. These seemingly unusual characteristics of the Marshallese community might occur in other Pacific Island migrant communities were it not for international barriers.

\section{Orange County Marshallese Community CharaCteristics}

With the high birth rate and the many arrivals of youth for education, the Orange County Marshallese population is young, with a mean age of 20.7 years. Age patterns differ by gender (table 3 ). Under age twenty there are more males than females, with a sex ratio for that age group of I.4 I. Over age forty there are many more women than men, with a sex ratio of only $0.4 \mathrm{I}$. The net effect is that the mean female age (22.7 years) is greater than the mean male age (I 8.9 years). This pattern may reflect Marshallese gender roles. Marshallese matrilineages control vital economic resources. Mothers form the core of Marshallese families, whereas the father is seen

Table 3. Marshallese in Orange County by Age and Sex, I99I

\begin{tabular}{lrrrrr}
\hline & \multicolumn{2}{c}{ Number } & & \multicolumn{2}{c}{ Percent of total } \\
\cline { 2 - 3 } \cline { 5 - 6 } Age & Male & Female & & Male & Female \\
\hline $0-09$ & 46 & 34 & & 17 & 12 \\
$10-19$ & 37 & 25 & & 13 & 9 \\
$20-29$ & 29 & 32 & & 10 & 12 \\
$30-39$ & 31 & 20 & & 11 & 7 \\
$40-49$ & 6 & 9 & & 3 \\
$50-59$ & 0 & 2 & & 0 & 1 \\
$60-69$ & 0 & 3 & & 0 & 1 \\
$70+$ & 1 & 3 & & 54 & 46 \\
Total & 150 & 128 & & 100 & \\
Both sexes & 278 & & & & \\
\hline
\end{tabular}

Source: Hess, Nero, and Burton I99I 
as a more transitory figure who moves among female-centered families. Marshallese endorse a common aphorism: "Our mother is ours alone, but our father is the father of others." Women over forty, most of whom are fairly recent arrivals, are elders who have come to visit family members and to provide help, guidance, or management of family affairs. ${ }^{3}$

Orange County Marshallese households, with a mean of 6.9 residents, are smaller than those in urbanized Majuro Atoll (8.6) or the Marshall Islands as a whole (8.7; RMI I989). As in the Marshalls, households in Orange County vary considerably in size, ranging from 2 to I 8 occupants, and household composition principles are similar in both places (Burton, Nero, and Hess 2000). Couple-based households are in the minority (I7 of 43 households). Most households (25) consist of extended families, either vertically (9) or horizontally (I6). These families are often based on same- and cross-sex sibling sets, as in the Marshall Islands.

In the early I990s, much of Orange County Marshallese community life revolved around the Jake Jobol Eo Club. This club sponsors a music group, the Navigators, which performs at the annual Pacific Islanders Festival in Long Beach, California, at social gatherings of other Pacific Islanders, and at Marshallese community events. In 1989, during the first year of our research, this band went on tour in the Marshall Islands, where they performed at a dinner for the new Japanese ambassador to the young nation. The performances included dances by a youth group, for some of whom it was their first view of the Marshalls since they had been toddlers.

During the late I990s, community life has placed more emphasis on church groups, which now include both the Assemblies of God and the main Marshallese denomination, the "Protestant" or United Church of Christ, who worship in the Corona del Mar Congregational Church. This church, a replica of a traditional New England church, is located in one of the most expensive neighborhoods in California, reflecting the role of religion in extending the social capital available to the community. Other important community events include first birthdays (kemem), graduations, and visits by Marshallese from other communities.

Consistent with the community's focus on education, adult Orange County Marshallese have relatively high levels of education-an average of I 2.9 years for men and I 2.5 years for women. Among those over age twenty-five, 94 percent of the men and 75 percent of the women have at least twelve years of schooling, while the comparable figures for the Marshall Islands are 40 percent and 24 percent, respectively. Most men (67 
percent) and many women (40 percent) have some education past high school (table 4). ${ }^{4}$ However, while many have attended college, few resident community members have completed a tertiary program. Most of the college graduates have returned to the Marshall Islands, where they have access to good government jobs. ${ }^{5}$ Conversely, those who left their homeland for education and did not complete their studies tend to stay in California. When discussing the possibility of return, some said they first desired to complete what they "set out to do," that is, acquire a college degree. A former resident of the United States, interviewed in Majuro, said that someone who had not finished school might fear being thought a failure and be reluctant to return.

In I99I, 22 Orange County Marshallese students, I 3 males and 9 females, were enrolled in tertiary institutions. Most were enrolled in twoyear community colleges, with just one in a four-year college. Most were from nineteen to twenty-five years of age; 39 percent of those in that range were enrolled in college. Community members had a high rate of participation in higher education, but few recent arrivals had come to attend college. Because of the perception that youth in school with other Micronesians spend too much time socializing and fail to complete their work, current Marshallese practices place college students in schools that have few other Micronesian students. College-age students were often directed

Table 4. Educational Achievement of Marshallese Aged 25 or More, by Residence and Sex, in Percent

\begin{tabular}{lcccccccc}
\hline \multirow{2}{*}{$\begin{array}{l}\text { Highest } \\
\text { Grade }\end{array}$} & \multicolumn{3}{c}{ Marshall Islands } & & \multicolumn{3}{c}{ Orange County } \\
\cline { 2 - 3 } \cline { 7 - 9 } \cline { 6 - 8 } & Male & Female & Both & & Male & Female & Both \\
\hline $0-7$ & 22.4 & 32.1 & 27.2 & & 2.0 & 8.3 & 5.2 \\
8 & 18.1 & 24.7 & 21.2 & & 2.0 & 6.3 & 4.1 \\
$9-11$ & 19.9 & 18.6 & 19.3 & & 2.0 & 10.4 & 6.2 \\
12 & 23.8 & 17.4 & 20.6 & & 26.5 & 35.4 & 30.9 \\
$12+$ & 15.8 & 6.8 & 11.5 & & 67.3 & 39.6 & 53.6 \\
Total & 100.0 & 100.0 & 100.0 & & 100.0 & 100.0 & 100.0 \\
Number & 7,029 & 6,620 & 13,649 & & 49 & 48 & 97 \\
\hline
\end{tabular}

Sources: RMI 1989; Hess, Nero, and Burton I99I. 
away from Orange County. Further, an increasing number of youths were being sent for vocational training with the Job Corps. There, it was believed, youth are supervised and supported more effectively than if they were on their own in regular vocational schools or colleges.

In interviews, community members discussed the transition from school to work. Lucky arrived in Costa Mesa when he was fourteen and completed high school and two years of junior college. When interviewed he said, "My parents wanted me to finish my high school and then they said it's up to me whatever I wanted to do. But as I know they really wanted me to study about business but I wasn't really interested in business and I just study my goal which is mechanics. . . . I wanted to be a mechanic at any car garage .... And I just want to work here in Costa Mesa, California." His family owns a small business on Ebeye. When asked about any plans to return home to help his family, he said, "I'll look for a job on Kwajalein, as my sister and I take care of their business. As planned, my mother wanted to build another business in Majuro so maybe I'll take care of the one in Majuro, as my sister stayed in Ebeye. And also maybe I'll open a garage shop for myself if I finish my education, if not I'll look for job and attend the training program on Kwajalein. I also want to go back and maybe build a house near my father's graveyard."

Orange County Marshallese households have a high employment rate. In this respect they contrast with many Pacific Islander migrants, who often experience high rates of unemployment. All households have at least one employed member, and the modal household (2 I of 43) has one male and one female employed (table 5). Fifteen households have more than two people employed. Ages of employed Marshallese range from twenty to forty-nine (table 6). Within this age range 79 percent of all men and 74 percent of all women were employed in 1991. With 58 employed men and 46 employed women, women constituted 44 percent of all wage employees - a high rate of women's labor force participation. However, like Emiko and Lucky, many in the Marshallese community have less education than they had originally aspired to, and most community members work in blue-collar jobs even when they have some college education. Many men and a few women are machinists, a number of the men working for a company that subcontracts jobs for the aerospace industry. The modal occupation for women is assembly of medical devices. Anitha, working on an assembly line for a manufacturer of artificial heart valves, demonstrated her competence during a crisis, was made a supervisor, then helped other Marshallese women, including Emiko, get jobs with the company. 
Some Marshallese, mostly women, work in clerical positions. Typical managerial jobs are tied to production, such as a shift supervisor. A few people with two- or four-year college degrees work in accounting, legal, and insurance jobs. The occupational structure for Orange County differs from that in the Marshall Islands in having fewer professional and technical jobs, many more production and transport jobs (6I percent of the total), and no jobs in agriculture and fishing (table 7). The occupational structure partly replicates Lieber's (I977a) finding for Kapingamarangi in relationship to Pohnpei: occupations in the community of origin diversify

Table 5. Numbers of Men and Women Employed per Household, I99I

\begin{tabular}{lcccc}
\hline \multirow{2}{*}{$\begin{array}{l}\text { Number of men employed } \\
\text { in each household }\end{array}$} & $\begin{array}{c}\text { Number of households by number } \\
\text { of women employed in each (o-2) }\end{array}$ & $\begin{array}{c}\text { Total } \\
\text { households }\end{array}$ \\
\cline { 2 - 3 } & 0 & 1 & 2 & 2 \\
0 & 0 & 1 & 1 & 28 \\
1 & 4 & 21 & 3 & 10 \\
2 & 1 & 4 & 5 & 2 \\
3 & 1 & 0 & 1 & 1 \\
4 & 1 & 0 & 0 & 43 \\
Total households & 7 & 26 & 10 & \\
\hline
\end{tabular}

Source: Hess, Nero, and Burton 1991.

Table 6. Employment by Age Group and Sex, in Percent

\begin{tabular}{crc}
\hline Age Group & Male & Female \\
\hline $20-24$ & 47.4 & 61.9 \\
$25-29$ & 84.6 & 66.7 \\
$30-34$ & 95.0 & 92.9 \\
$35-39$ & 75.0 & 85.7 \\
$40-49$ & 100.0 & 66.7 \\
\hline
\end{tabular}

Source: Hess, Nero, and Burton I99I. 
as involvement with the world system creates new roles, whereas in the context of the migrant community many of these roles are filled by other groups, and occupations are less diversified. Racial discrimination may also be an issue, as Macpherson, Bedford, and Spoonley (2000) have suggested for New Zealand S moans, but we believe the possibility of high government jobs in Majuro and Ebeye for graduates has historically been a more important factor.

Jobs are often located through other Marshallese. Another popular strategy is to sign on with a temporary employment services agency. This practice allows people to find out whether they like the job and the workplace; if they do they can try to be hired as permanent employees. For other Marshallese, temporary work allows the flexibility to mix periods of employment with periods of family or community activity, a practice that enables them to maintain continuity with a common Islander practice of targeting labor for specific cash needs.

Table 7. Economic Activity of Marshallese Aged I 5 Years and Over, by Location

\begin{tabular}{|c|c|c|c|c|}
\hline \multirow[b]{2}{*}{ Occupation } & \multicolumn{2}{|c|}{ Marshall Islands } & \multicolumn{2}{|c|}{ Orange County } \\
\hline & Number & Percent & Number & Percent \\
\hline \multicolumn{5}{|l|}{ White collar } \\
\hline Professional, Technical & 1,682 & 16.0 & 6 & 5.9 \\
\hline Managerial, Administrative & 265 & 2.6 & 9 & 8.9 \\
\hline \multicolumn{5}{|l|}{ Service } \\
\hline Clerical and related & 902 & 9.0 & 10 & 9.9 \\
\hline Sales & 501 & 5.0 & 3 & 3.0 \\
\hline Other & 1,322 & 13.1 & 2 & 2.0 \\
\hline \multicolumn{5}{|l|}{ Blue collar } \\
\hline Production, Transport & 3,249 & 32.3 & 61 & 60.4 \\
\hline Agriculture, Fishing & 2,129 & 21.2 & 0 & 0.0 \\
\hline Not given & 6 & 0.1 & 10 & 9.9 \\
\hline Total & 10,056 & 100.0 & 101 & 100.0 \\
\hline
\end{tabular}

Sources: RM I 1989; Hess, Nero, and Burton I99I. 


\section{Community Ties}

The geographical extension of Marshallese households now includes the United States. Marshallese who live there maintain ties to households in the Marshall Islands. They may speak of "my" house in the Marshalls, although they have not resided in the Marshall Islands for many years, and the island house is now occupied by a relative. Similarly, when Marshallese come from the islands they usually reside with relatives, reinforcing ties to family members who left earlier. United States-resident Marshallese continue to discuss and legitimate household membership in the idiom of kinship, even though links within households might be more extended than is normal in the islands. ${ }^{6}$

Describing his home communities, Hermond said, "My father's from Likiep, Arno, Mili, Wotje, Mejit, and Utirik. And my mother is from Majuro, Kwajalein, Namu, Ailinglaplap, Maloelap, Wotje, Aur.” Like Hermond, most Marshallese often have social ties through the father's side and the mother's side to a number of atolls, ties that often involve land rights. In the Orange County community, most of these ties are to just a few atolls. We asked 43 Marshallese from the community to list their home island or atoll, ${ }^{7}$ and the birthplace of their father and mother. Out of 127 responses to these three questions, 67 listed just 5 atolls out of the 24 inhabited locations: Majuro (I6), Jaluit (I4), Kwajalein (I4), Likiep (I3), and Ailinglaplap (го). Other frequent mentions included Mejit (9), Ebon (7), Wotje (7), Namdrik (7), and Arno (6). We also asked people where they had land rights and obtained similar responses.

Orange County Marshallese tend not to be from the so-called nuclear atolls that receive compensation from the US government. Of the locations included in the nuclear claims compensation program, two people had ties to Utrik, one had ties to Enewetak, and one has ties to Rongelap. Bikini and Kili were not listed. In contrast with these minimal links with the "nuclear atolls," the Enid, Oklahoma, community studied by Allen (I997) includes a group of Bikini relocatees, and nuclear claims money plays an important role in Enid community politics.

Although the Orange County community does not benefit substantially from nuclear claims transfer payments, it shares with the Enid community an unusual pattern of remittances. In both communities the net flow of remittances is from the Marshall Islands to the migrant community. We have not seen this pattern reported for any other migrant community in the United States. These remittances are linked to the high value placed on education in the community. 


\section{Exchanges with Relatives in the Marshall Islands}

Education has played a key role in forming Marshallese migrant communities, and it is a major focus of social exchanges between Marshallese in Orange County and their relatives in the islands. In interviews, Marshallese migrants usually focused on getting a good job as the reason to get an education. Many of them considered several options when they made education decisions, including Guam, other Micronesian locations, Hawai' $i$, and the mainland United States. The options tended to be within the US world system, and they have been influenced by changes in US government policies. More recently, since independence, new alliances and aid programs have opened opportunities in Australia, Fiji, Japan, and New Zealand.

A young man reported on exchanges with his family in the islands: "When my father was still alive, sometimes I used to send him a tee-shirt. But my mother always sent me things .... Sometimes people send money to buy something for them. My mother used to send me money, but after I was working she stopped or unless I asked her .... My auntie sometimes sent me money to help me out even though I was not asking-she sent me (something) every other month. My parents sometimes wire up to $\$ 5,000$ maximum and my auntie about \$200 maximum.”

The focus on education in the Marshallese migrant community has produced an unusual pattern of exchanges with relatives in the home islands. In 1993 we surveyed a sample of 43 community members over the age of fourteen. Of these, 28 reported some kind of exchange. Of those reporting exchanges, 8 reported sending goods home in the past year and 8 reported sending goods and money; I I received money and I received money and sent goods. Goods sent included clothing (by far the largest category), perfume, foods, birthday gifts, and pictures (mentioned by I or 2 individuals). Although no respondents reported receiving goods from the Marshall Islands, we know from our own observations that Marshallese foods and handicrafts are often brought by visitors.

Those who received money listed the following purposes for it: school (6), clothing (2), rent (I), medical expenses (I), and basic necessities (3). In three of the $\mathrm{I} 2$ cases the money was paid to the household head on behalf of the individual. The value of money received (estimated at $\$ 23,000)$ exceeded the value of goods and money $(\$ 6,250)$ sent home by a ratio of nearly four to one. ${ }^{8}$

Nearly half of the 32 exchanges reported involved transfers from parents to children-I I remittances of money from the Marshall Islands to 
Orange County and 3 transfers to children in the Marshalls. Children in Orange County made 9 transfers of goods and money to parents or grandparents in the Marshalls. Another 7 exchanges involved siblings, where transfers from Orange County to the Marshalls dominated by 6 to I. Two transfers were made from Orange County to "family." Hence, not only is the net flow of wealth from the Marshall Islands to the migrant community, but transfers to older generations make up less than one-third of all exchanges. This is the opposite of the usual Pacific Island pattern in which remittances are sent from the migrant community to elders at home. The pattern is made possible by the position of the Marshallese nation in the global system, in which money flows to the Marshall Islands from the United States, based on US strategic interests.

\section{Marshallese Places in Context}

World systems theories emphasize the geographic distribution of economic opportunities across a global political economy, and educational opportunities correlate with economic level. We postulated that the comparison of Marshallese communities at different levels of the world system should reveal this distribution of opportunities. Orange County is closely tied to Los Angeles, a "global city." Majuro, the capital and center for social services, is an urbanized atoll with direct international air and shipping services. The rural atolls have economies based on a mixture of subsistence production, earnings from copra, government jobs such as teaching, and exchanges with family members who have wage jobs in Majuro or Ebeye.

Table 8 compares occupation statistics for different Marshallese residence sites, showing concentration of students in the semi-periphery and core, and reproductive work in the periphery. The percentage of students is 2.5 times higher in Majuro than in the rural locations, where there are few schools that offer classes beyond the eighth grade. The lower percentage of people listed as homemakers in Majuro reflects women's desires to earn money, unwaged labor in family businesses, and the higher urban cost of living. Moving to the data from Orange County, we see lower unemployment, fewer women defined as homemakers, and twice as many students.

These factors are reflected in the age structures shown in table 9. Children under age ten are concentrated increasingly toward the periphery, where the costs of social reproduction are met primarily by household subsistence production. When children get older, many are sent to urban 
Table 8. Economic Activity of Marshallese I5 Years and Over, by Location, in Percent

\begin{tabular}{lrrr}
\hline & \multicolumn{2}{c}{ Marshall Islands } & \\
\cline { 2 - 3 } Location & Rural & Majuro & Orange County \\
\hline Monetized Labor Force & & & \\
$\quad$ Employed & 55 & 45 & 58 \\
$\quad$ Unemployed & 3 & 9 & 2 \\
Non-monetized Labor Force & & & \\
$\quad$ Homemaker & 30 & 24 & 5 \\
$\quad$ Student & 6 & 15 & 29 \\
$\quad$ Retired & 4 & 5 & 5 \\
$\quad$ Other & 1 & 1 & 0 \\
Total & 100 & 100 & 100 \\
Number & 6,648 & 10,324 & 173 \\
\hline
\end{tabular}

Sources: RMI I989; Hess, Nero, and Burton I99I.

Table 9. Marshallese Population Age Structure for Outer Islands, Majuro, and Orange County (Percent)

\begin{tabular}{lcrc}
\hline & \multicolumn{2}{c}{ Marshall Islands } & \\
\cline { 2 - 3 } Age & Outer Islands & Majuro & Orange County \\
\hline $0-9$ & 42 & 34 & 29 \\
$10-19$ & 22 & 24 & 22 \\
$20-29$ & 14 & 16 & 22 \\
$30-39$ & 10 & 12 & 18 \\
$40-49$ & 5 & 6 & 5 \\
$50-59$ & 3 & 4 & 1 \\
$60-69$ & 3 & 3 & 1 \\
$70+$ & 2 & 2 & 2 \\
Total & 100 & 100 & 100 \\
\hline
\end{tabular}

Sources: RMI 1989; Hess, Nero, and Burton I99I. 
areas for education. The slight dominance of Majuro for I0-I9 year olds is suggestive of this trend, although not statistically significant. The trend might be expected given the lower costs of educating a student in Majuro. Investments and resources are allocated across differentiated opportunities. Because the educational and employment opportunities in Majuro become more limiting when a person is ready for tertiary schooling and wage jobs, the percentage of people in the 20-29 and 30-39 age groups increases with locations closer to the world system core. This pattern flattens out in the 40-49 age category, reflecting the brief time depth of this particular migration system; the first few arrivals were entering their forties at the time of our I99I census.

One way of summarizing the distribution of people through the economic system is by comparing the dependency ratios for each locale - that is, the ratio of people under 15 and people over 65 , presumed to be economically inactive, to people between ${ }_{5} 5$ and 65 . The ratio for the rural Marshall Islands is I.50; for Majuro, 0.99; for Orange County, 0.63. This increasing concentration of people of working age ( $16-64)$ in central locations reflects the geographical distribution of opportunities and costs.

Overall, these data show that education and employment of Marshallese in Orange County extend patterns found in the Marshall Islands, and the two locations are integrated by economic and social processes. All of the data can be interpreted as the rational allocation of family members to different settings within a transnational system.

\section{Conclusion}

The Orange County Marshallese seem at first to be an exception to the usual Pacific Island migration patterns. Money flows from the islands to the migrant community; resources flow from parents to their children; and children are sent to the migrant community to get a good education so that they can compete for good jobs in the islands and abroad. However, we think these patterns are manifestations of cultural practices similar to those reported elsewhere. The differences are due to the unique relationship between the Marshall Islands (and the other freely associated states) and the United States. Other factors include the short time span of this overseas community, compared with other overseas communities. The different circumstances in the relationship of the Marshallese and other Micronesians with the United States will, however, result in continuing differences in the immigrant communities as they mature. We expect these 
may generalize to other overseas communities whose metropolitan relationships differ from those with New Zealand and Australia.

Goodenough first made the argument that similar cultural principles will produce different social patterns, depending upon the macroscopic context (I955). Island social systems have historically emphasized flexible adaptations and the possibility of migration to seek new resources. Family members move freely between locations depending on circumstances. Colonial and neocolonial labor policies have interfered with that flexibility in that Islanders were allowed (or forced) to migrate for special purposes, mainly employment and education. The ability to bring along other family members was minimal, producing "split" families, with wage earners living in the migrant community and youth and elders living at home (Barker 1994).

For residents of the former US Trust Territory of the Pacific Islands, the compacts of free association have lifted these restrictions. Now Marshallese can bring elders to the United States to manage their families and can send youth to live with distant relatives for purposes of education. What remains constant is the emphasis among migrants on trans-Pacific exchanges.

The Marshallese case, while supporting the importance of economics in migration processes, also demonstrates the danger of reducing social processes to a narrow version of economics. The Marshallese islands were connected to metropolitan regions by transnational institutions, involving religious, colonial, and military ties. These ties formed the context in which migration has been supported between the Marshalls and the United States. Through these connections and a few key individuals, the Marshallese established social and geographic centers around which communities have formed, gathering people who had initially established residence in other locales.

Although Marshallese migration contrasts with the general Pacific pattern of migration for labor and remittances, it also replicates a familiar story of Islanders' travel in pursuit of a goal, with intentions of ultimately returning home (eg, O’Meara 1993). Falling short of the requirements for "bootstrapping" (Marcus I993), they remain abroad. While abroad, however, they continue to serve as resources for their families by supporting future migration, and as resources for their country in its pursuit of economic development.

Some analysts may focus on wages and remittances, and on the economic "dependence" of the Marshallese, but we suggest that a longer-term 
perspective is required. Our data demonstrate that the Marshallese are choosing investment as well as consumption-investment in developing human resources and in building social networks for the pursuit of economic and political goals. This strategy is practical because of the level of US transfer payments and the support of international development agencies. The strategy of investment is supported at state, community, and household levels. Investment strategies must be understood with reference to access to metropolitan resources and to possibilities of maintaining households and communities that cross international boundaries.

JIM HESS CONDUCTED THE PRIMARY ethnographic research, with the assistance of five Marshallese community members. The project had the formal approval of the community organization, Jake Jobol Eo Club (JJEC). We have made information from our study available to the local and home Marshallese communities, and community members have commented on drafts of this paper. We especially wish to thank George Briand, former president of Jake Jobol Eo, the JJEC Board of Directors, and Bue Garstang, Que Keju, Taraur Ria, Lilly Ria, Neibaj Silk, and Josephine Wase. This research was funded by a gift from Dr Robert Gumbiner and by the University of California Pacific Rim Program.

\section{Notes}

I Recently renamed Vanguard University of Southern California.

2 All informants' names are pseudonyms.

3 The Enid, Oklahoma, community has a different pattern, with more young women than young men, and equal numbers of men and women over age forty.

4 A loglinear analysis shows that levels of education vary with location and gender, and gender with location, but that the variation in the relationship between gender and education across locations is not statistically significant.

5 Based on personal observation and confirmed by community members and personal communication with Hilda Heine, former secretary of education of the Marshall Islands.

6 Our informants said that households should be formed among kin, since friendships may not be strong enough to withstand the stresses of living together. However, our survey assistants noted several cases where a closer relationship, such as cousin, was used to label a more distant clan connection. They said this occurred because not enough closer relatives were available to join in households. 
7 We let respondents decide what this meant. It usually referred to land rights rather than de facto residence. Most Orange County Marshallese resided in an urban center prior to their move to the United States.

8 In her study of the Enid, Oklahoma, community, Linda Allen reported an even higher ratio of remittances received to remittances sent-nearly 7 to I (1997, I93-I96).

\section{References}

Ahlburg, Dennis A, and Michael J Levin

1990 The Northeast Passage: A Study of Pacific Islander Migration to American Samoa and the United States. Canberra: National Centre for Development Studies, Australian National University.

Alexander, William J

I978 Wage Labor, Urbanization, and Cultural Change in the Marshall Islands: The Ebeye Case. PhD dissertation, New School for Social Research, New York.

Alkire, William

I989 Lamotrek Atoll and Inter-Island Socioeconomic Ties. Second edition. Urbana: University of Illinois Press. First edition 1965. (Prospect Heights: Waveland Press).

Allen, Linda

I997 Enid "Atoll": A Marshallese Migrant Community in the Midwestern United States. PhD dissertation, Department of Anthropology, University of Iowa, Iowa City.

Barker, Judith

I994 Home Alone: The Effects of Out-Migration on Niuean Elders' Living Arrangements and Social Supports. Pacific Studies I7 (3): 4I-8I.

Basch, Linda, Nina Glick Schiller, and Cristina Szanton Blanc

1994 Nations Unbound: Transnational Projects, Postcolonial Predicaments and Deterritorialized Nation-States. New York: Gordon and Breach.

Bertram, I Geoffrey, and Ray F Watters

I985 The mirab Economy in South Pacific Microstates. Pacific Viewpoint

Bourdieu, Pierre 26 (3): 497-5 I9.

I985 The Forms of Capital. In Handbook of Theory and Research for the Sociology of Education, edited by J G Richardson, 24I-258. New York: Greenwood.

Burton, Michael L, Karen L Nero, and Jim Hess

2000 Correspondence Analysis of Household Resources in Marshallese Communities. Society for Cross-Cultural Research. Sessions in honor of A K Romney. New Orleans, February 2000. 
Carucci, Laurence M

I997 Nuclear Nativity: Rituals of Renewal and Empowerment in the Marshall Islands. Dekalb, IL: Northern Illinois University Press.

Chavez, Leo

I985 Households, Migration and Labor Market Participation. Urban Anthropology I4:30I-345.

Coleman, James S

I988 Social Capital in the Creation of Human Capital. American Journal of Sociology 94:S95-S I 20.

Connell, John

I983 Migration, Employment, and Development in the South Pacific, volume 3: Country Report 3: Federated States of Micronesia. Noumea: South Pacific Commission.

Connell, John, and Dennis A Ahlburg

I986 Population and Economic Development in the Island Nations of the South Pacific. In Selected Issues in Pacific Island Development, edited by Rodney V Cole and T G Parry, 2 I-70. Canberra: National Centre for Development Studies, Australian National University.

DaVanzo, Julie

I98I Repeat Migration, Information Cost, and Location Specific Human Capital. Population and Environment 4 (I): 45-73.

Franco, Robert W

I993 Movement Networks and "Relative" Economies in Samoa and Micronesia. In A World Perspective on Pacific Islander Migration: Australia, New Zealand and the USA, edited by Grant McCall and John Connell, I6I-I70. Sydney: Centre for South Pacific Studies, University of New South Wales.

Gailey, Christine Ward

I992 A Good Man Is Hard to Find: Overseas Migration and the Decentered Family in the Tongan Islands. Critique of Anthropology I 2:47-74.

Goodenough, Ward

I955 A Problem in Malayo-Polynesian Social Organization. American Anthropologist 57 (I): 7 I-83.

Gorenflo, L J, and Michael J Levin

I995 Changing Migration Patterns in the Federated States of Micronesia. ISLA: A Journal of Micronesian Studies 3:29-7 I.

Grosfoguel, Ramon, and Hector Cordero-Guzman

I998 International Migration in a Global Context: Recent Approaches to Migration Theory. Diaspora 7 (3): 35 I-368.

Gupta, Akhil, and James Ferguson, editors

I997 Anthropological Locations. Berkeley: University of California Press. 
Hannerz, Ulf

I992 Cultural Complexity. New York: Columbia University Press.

Hayes, Geoffrey

I992 The Use of Scientific Models in the Study of Polynesian Migration. Asian and Pacific Migration Journal I (2): 278-3I 2.

Hess, Jim, Karen L Nero, and Michael L Burton

I99I Southern California Marshallese Household Census. Department of Anthropology, University of California, Irvine.

Hezel, Francis X

I983 The First Taint of Civilization: A History of the Caroline and Marshall Islands in Pre-Colonial Days, I52I-I885. Pacific Islands Monograph Series I. Honolulu: Center for Pacific Islands Studies and University of Hawai'i Press.

Hezel, Francis X, and Michael J Levin

I987 Micronesian Emigration: The Brain Drain in Palau, Marshalls, and the Federated States. Journal of the Pacific Society 29: I6-34.

James, Kerry

I997 Reading the Leaves: The Role of Tongan Women's Traditional Wealth and Other Contraflows in the Processes of Modern Migration and Remittance. Pacific Studies 20 (I): I-27.

Kiste, Robert C

I974 The Bikinians: A Study in Forced Migration. Menlo Park, CA: Cummings.

I993 New Political Statuses in American Micronesia. In Contemporary Pacific Societies: Studies in Development and Change, edited by V S Lockwood, T G Harding, and B J Wallace, 67-80. Englewood Cliffs, NJ: Prentice Hall.

Lieber, Michael D

I977a The Processes of Change in Two Kapingamarangi Communities. In Lieber $1977 \mathrm{~b}, 35-67$.

Lieber, Michael D, editor

I977b Exiles and Migrants in Oceania. As Ao Monograph 5. Honolulu: University of Hawai'i Press.

Linnekin, Jocelyn, and Lin Poyer

1990 Introduction. In Cultural Identity and Ethnicity in the Pacific, edited by Jocelyn Linnekin and Lin Poyer, I47-I73. Honolulu: University of Hawai'i Press.

Macpherson, Cluny

I994 Changing Patterns of Commitment to Island Homelands: A Case Study of Western Samoa. Pacific Studies I7 (3): 83-I I 6.

Macpherson, Cluny, Richard Bedford, and Paul Spoonley

2000 Fact or Fable? The Consequences of Migration for Educational 
Achievement and Labor Market Participation. The Contemporary Pacific I2:57-82.

Marcus, George E

1993 Tonga's Contemporary Globalizing Strategies: Trading on Sovereignty amidst International Migration. In Contemporary Pacific Societies: Studies in Development and Change, edited by V S Lockwood, T G Harding, and B J Wallace, 2 I-33. Englewood Cliffs, NJ: Prentice Hall.

Mason, Leonard

I954 Relocation of the Bikini Marshallese: A Study in Group Migration. $\mathrm{PhD}$ dissertation, Yale University, Newhaven, Ст.

1989 A Marshallese Nation Emerges from the Political Fragmentation of American Micronesia. Pacific Studies I 3:I-46.

Massey, Douglas S, Joaquin Arango, Graeme Hugo, Ali Kouaouci, Adela Pellegrino, and J Edward Taylor

I993 Theories of International Migration: A Review and Appraisal. Population and Development Review I9 (3): 43I-466.

McArthur, Phillip

I995 The Social Life of Narrative: Marshall Islands. PhD dissertation, Indiana University, Bloomington.

MIJ, Marshall Islands Journal

I999 Census Shocker: Only 50,865 in RMI. Marshall Islands Journal, I7 December.

Nero, Karen L

I997 The End of Insularity: Islander Paradigms for the Pacific Century. In The Cambridge History of the Pacific Islanders, edited by Donald Denoon, Stewart Firth, Jocelyn Linnekin, M lama Meleise , and Karen Nero, 439-467. Cambridge: Cambridge University Press.

Nero, Karen L, and Faustina K Rehuher

I993 Pursuing the Dream: Historical Perspectives on Micronesian Movement Patterns. In A World Perspective on Pacific Islander Migration: Australia, New Zealand and the USA, edited by Grant McCall and John Connell, 239-255. Sydney: Centre for Pacific Studies, University of New South Wales.

O'Meara, Timothy

I993 The Cult of Custom Meets the Search for Money in Western Samoa. In Contemporary Pacific Societies: Studies in Development and Change, edited by V S Lockwood, T G Harding, and B J Wallace, I35-I 55. Englewood Cliffs, NJ: Prentice Hall.

Peattie, Mark R

I988 Nan'y : The Rise and Fall of the Japanese in Micronesia, I885-I945. Pacific Islands Monograph Series 4. Honolulu: Center for Pacific Islands Studies and University of Hawai'i Press. 
Poirine, Bernard

I998 Should We Hate or Love MiRAB? The Contemporary Pacific I0:65I05.

Portes, Alejandro, and Julia Sensenbrenner

I993 Embeddedness and Immigration: Notes on the Social Determinants of Economic Action. American Journal of Sociology 98 (6): I320-I350.

Ravuvu, Asesela

I992 Security and Confidence as Basic Factors in Pacific Islanders' Migration. Journal of the Polynesian Society IOI:329-34I.

RMI, Republic of the Marshall Islands

I989 Census of Population and Housing I988: Final Report. Majuro: Office of Planning and Statistics.

Rynkiewich, Michael A

I972 Land Tenure among the Arno Marshallese. PhD dissertation, University of Minnesota, Minneapolis.

Salt, John

I989 A Comparative Overview of International Trends and Types. International Migration Review 23:43 I-456.

Shmull, Temmy L

I978 Micronesian Students in Western Schools. In New Neighbors: Islanders in Adaptation, edited by ClunyMacpherson, Bradd Shore, and Robert Franco, I85-190. Santa Cruz, CA: Center for South Pacific Studies, University of California, Santa Cruz.

Small, Cathy

I997 Voyages: From Tongan Villages to American Suburbs. Ithaca, NY: Cornell University Press.

Spoehr, Alexander

I949 Majuro, a Village in the Marshall Islands. Chicago: Chicago Natural History Museum.

Tobin, Jack A

I954 Kili Journal, August 28 to September I8, I954. Mimeographed. Majuro, Marshall Islands: Trust Territory of the Pacific Islands.

I967 The Resettlement of the Enewetak People: A Study of a Displaced Community in the Marshall Islands. PhD dissertation, Department of Anthropology, University of California, Berkeley.

Underwood, Jane $\mathrm{H}$

I989 Population History of Nauru: A Cautionary Tale. Micronesica 22:3-22. Westbrook, George E L

I935 Gods Who Die: The Story of Samoa's Greatest Adventurer, as told to Julian Dana. New York: Macmillan.

Wood, Charles H

I982 Equilibrium and Historical-Structural Perspective on Migration. International Migration Review I6:298-3I9. 
Yamamoto, Matori

I997 Samoan Diaspora and Ceremonial Exchange. In Contemporary Migration in Oceania: Diaspora and Network, edited by K Sudo and S Yoshida, 65-76. Osaka: Japan Center for Area Studies.

\section{Abstract}

Founded by individuals pursuing higher education in the United States, the Marshallese community in Orange County today also represents family and national interests in access to business opportunities, employment, education, medical services, and other goals. This community has become an "official” Marshallese overseas community, site of the first Marshallese consulate in the mainland United States, and a link between overseas Marshallese and the home islands. Individuals and family units traverse networks of inter-linked households, highlighting processes of Islanders' investments, including at least a short-term reversal of theoretically expected remittance flows. We explore the process of community formation, and compare rural and urban sites in the Marshall Islands to call attention to the community's place in a system of geographically dispersed locations within the global political economy.

KEYWORDS: community formation, exchange relationships, family relationships, Marshall Islanders, migrant communities, migration decisions, Orange County 